\title{
Lipase Activity in Vesicular Systems: Characterization of Candida cylindracea Lipase and Its Activity in Polymerizable Dialkylammonium Surfactant Vesicles
}

\author{
E.W. J. Mosmuller and M.C.R. Franssen \\ Department of Organic Chemistry, Wageningen Agricultural University, \\ Dreijenplein 8, 6703 HB Wageningen, The Netherlands \\ J.F.J. Engbersen* \\ Department of Organic Chemistry, Faculty of Chemical Technology, \\ University of Twente, P.O. Box 217, 7500 AE Enschede, The Netherlands
}

Received August 10, 1992/Accepted January 27, 1993

\begin{abstract}
Lipase from Candida cylindracea (CCL) was incorporated into polymerizable positively charged dialkylammonium bromide surfactant vesicles. The enzyme was incorporated by the use of the dehydration-rehydration method or by incubation. In the latter case, trapping efficiencies of up to $100 \%$ could be obtained. Activities of free and vesicle-incorporated $\mathrm{CCL}$ were tested for three triglycerides: triacetin, tributyrin, and tricaprylin. Enzyme activity was lowest in homogeneous mixtures (triacetin and small concentrations of tributyrin) and highest in heterogeneous mixtures (tricaprylin and high concentrations of tributyrin). Entrapment in vesicular systems is advantageous, especially in homogeneous reaction mixtures and in the case of the production of insoluble fatty acid (caproate), because inhibition by the acid can be suppressed. The influence of several surfaceactive additives, including vesicles, on the activity of lipase in triglyceride assays was tested. Vesicles have a positive influence on the activity, whereas other positively charged additives act as inhibitors. In the case of tricaprylin assays, the positively charged additives increase the activity. Finally, tryptic digestion for free and incorporated $\mathrm{CCL}$ were compared. Free $\mathrm{CCL}$ is readily inactivated, whereas incorporated enzyme is protected from proteolytic degradation. (C) 1993 John Wiley \& Sons, Inc.

Key words: Candida cylindracea lipase $(\mathrm{CCL}) \cdot$ interfacial activity - lipase purification - polymerizable surfactant vesicles • protein incorporation into vesicles • triglyceride hydrolysis
\end{abstract}

\section{INTRODUCTION}

Lipases (triacylglycerol acylhydrolases, EC 3.1.1.3) are a group of enzymes whose biological function is to hydrolyze triacylglycerol esters. Over the past years, traditional areas in which lipases have been applied are the detergent, ${ }^{38}$ oil and fat, ${ }^{28}$ and dairy and food industries. ${ }^{29}$ More recently, lipases have received growing attention for synthetic purposes, taking advantage of their ability to work in a low-water environment, their broad substrate specificity,

* To whom all correspondence should be addressed. and their regio- and stereoselectivity. ${ }^{20,22}$ Lipases perform their catalytic action at the substrate-water interface of heterogeneous reaction systems. It is well-known that the activity of these enzymes is dependent on the interfacial concentration of their substrates. Maximal activity is therefore observed when the substrate is emulsified or solubilized in a (co-)solvent in a two-phase system. ${ }^{3}$ Two major factors that control lipase activity are (i) the amount of substrate molecules present at the interface, which is proportional to the surface area of an emulsified substrate; and (ii) the surface quality. ${ }^{43}$

Vesicles are closed bilayer structures (see Fig. 1) that can be formed from a broad variety of (synthetic) amphiphilic molecules. ${ }^{33}$ Vesicular systems have proven to be systems with well-defined surface properties. ${ }^{9,12}$ Due to these characteristics, the use and application of vesicular systems is broad and versatile: they are used for the reconstitution of membrane proteins, ${ }^{8}$ as model systems in the study of biological recognition processes and dynamics of biomembranes ${ }^{33}$ and for the entrapment of all sorts of compounds, including enzymes. ${ }^{10,11}$ The stability or lifetime of vesicles can be improved by several strategies, for instance, by the use of polymeric surfactant molecules. ${ }^{33}$

For practical applications of enzyme-vesicle systems, e.g., for the stabilization of enzymes under denaturing conditions, the development of drug-targeting systems or in order to create microbioreactors, it is desirable to study enzyme vesicle interactions in more detail. Therefore, we were interested in the behavior of enzymes incorporated in polymerizable surfactant vesicles. ${ }^{25}$

We now present a study on lipase from Candida cylindracea (CCL) entrapped in vesicles composed of polymerizable surfactants. The lipase-vesicle system has been characterized in terms of activity and stability. We have compared the activity of incorporated versus free enzyme for three different triglycerides. Furthermore, we have investigated the protective effect of vesicles for proteolysis by trypsin and denaturation by surfactant additives. 


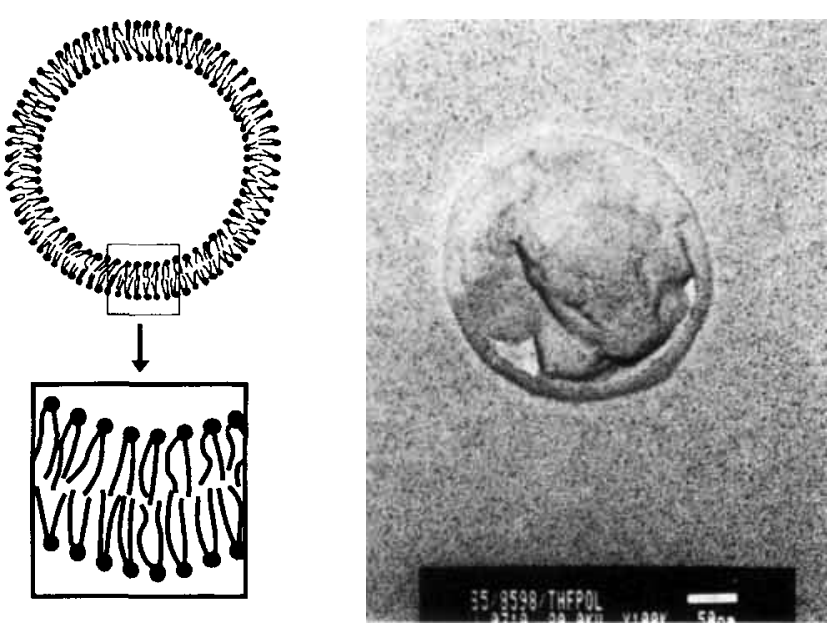

Figure 1. Schematic representation and electron micrograph of a polymerized ABHEMA $\mathrm{Br}$ vesicle (freeze-dried and subsequently platinum shadowed).

\section{MATERIALS AND METHODS}

\section{Materials}

Lipase from $C$. cylindracea was supplied by Meito Sangyo (lipase OF); azobisisobutyronitrile (AIBN; 98\%), poly(ethyleneimine) (PEI; $50 \mathrm{wt} \%$ aqueous solution, average MW 50,000 to 60,000), triacetin (99\%, distilled), and tris(hydroxymethyl)aminomethane (tris; $99+\%$ ) by Janssen Chimica. Methyl bromide $(99.5+\%)$ and polyoxyethylene(23)lauryl ether (Brij 35) were purchased from Aldrich and tributyrin (distilled) from Aldrich (98\%) and Janssen Chimica (98\%). Calcium chloride (p.a.) and $N$-cetyl- $N, N, N$-trimethylammonium bromide (CTAB; p.a.) were purchased from Merck, Sephacryl S-300 from Pharmacia, and tricaprylin (97\% to $98 \%$ ) and trypsin (bovine type XI) from Sigma. All organic solvents were distilled before use. All aqueous solutions were prepared in particle-free, demineralized and deionized water, purified by a Seralpur Pro $90 \mathrm{C} /$ Seradest LFM water purification system.

The quaternary dialkylammonium surfactants (see scheme) $N$-allylbis[2-(dodecanoyloxy)-ethyl]methylammonium Bromide (ABDEMA Br) ${ }^{41}$ and $N$-allylbis[2-hexadecanoyloxy)ethyl]-methylammonium bromide (ABHEMA $\mathrm{Br})^{18}$ were synthesized according to literature procedures. Bis/2-(10-undecenoyloxy)ethyl]dimethylammonium bromide (BUEDMA $\mathrm{Br}$ ) was prepared by the method of Tundo et al. $^{41}$ with the following modifications. Bis[2-(10undecenoyloxy)ethyl]methylamine $(2.3 \mathrm{~g}, 5 \mathrm{mmol})$ was heated for 5 hours in a saturated ethanolic methyl bromide solution at $60^{\circ} \mathrm{C}$. After removal of the solvent and the excess of methyl bromide, the crude product was crystallized twice from petroleum etherchloroform $25: 2(\mathrm{v} / \mathrm{v})$, to yield $2.6 \mathrm{~g}(95 \%)$ of bis[2-(10undecenoyloxy)ethyl]dimethylammonium bromide, m.p. $134^{\circ}$ to $137^{\circ} \mathrm{C}$. The NMR data of the surfactants are in full accordance with their structure.

\section{Vesicle Formation and Polymerization}

Monomeric vesicles were prepared by sonication of $5 \mathrm{mM}$ surfactant suspensions at $60^{\circ} \mathrm{C}$ using the standard $13-\mathrm{mm}$ tip of a VC-300 Sonics \& Materials sonifier, with output control set at level $8(60 \mathrm{~W})$. Slightly opaque solutions were obtained in about 10 to 20 minutes. Polymeric vesicles were prepared by the method described by Kippenberger et al. ${ }^{18}$ Alternatively, ABHEMA $\mathrm{Br}$ was polymerized before vesiculation. Therefore, AIBN $(1 \%$ to $5 \% \mathrm{w} / \mathrm{w}$ with regard to the surfactant) was added to $5 \mathrm{mM}$ surfactant solutions in tetrahydrofuran and was refluxed for 8 to 12 hours. The solvent was removed and a proper amount of water was added. The surfactants were then vesiculated by sonication; opaque solutions were obtained in 20 to 60 minutes. The polymerization process was followed by means of NMR. Monomeric or polymeric vesicle solutions were freeze dried and were then solubilized in deuterated pyridine or trifluoroacetic acid. The disappearance of the vinyl signal was taken as a measure for the degree of polymerization. NMR spectra were recorded on a Bruker $200 \mathrm{E}$ at $200 \mathrm{MHz}$. All vesicle solutions were centrifuged before further use for 30 minutes at $15,500 \mathrm{~g}$ in a Sigma $202 \mathrm{M}$ centrifuge in order to remove any titanium particles from the sonifier tip.

\section{Electron Microscopy}

Samples for the transmission electron microscope (JEOL $1200 \mathrm{EX}$ ) were rapidly frozen in liquid propane, partly freeze-dried in a BAF 400 freeze-fracturing apparatus (Baltzers Union, Liechtenstein), platinum shadowed at an angle of $40^{\circ}$, and coated with carbon. The replicas were floated off in distilled water, washed overnight in $20 \%$

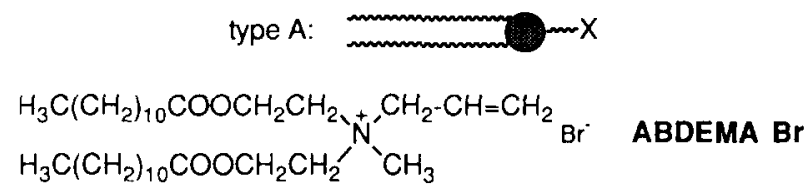

N-Allylbis[2-(dodecanoyloxy)ethyl]methylammonium Bromide

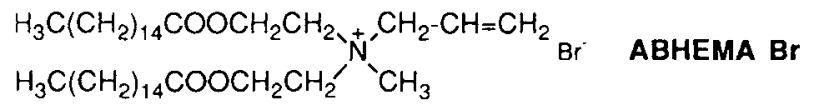

N-Allylbis[2-(hexadecanoyloxy)ethyl]methylammonium Bromide

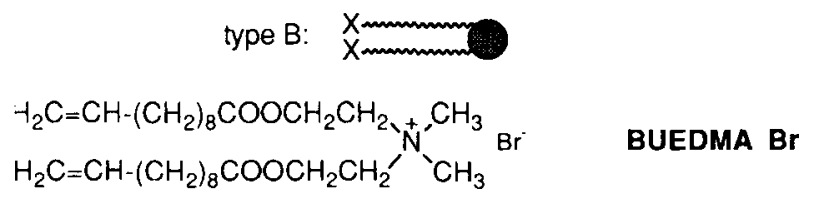

Bis[2-(10-undecenoyloxy)ethyl]dimethylammonium Bromide

Scheme. Surfactants used for the preparation of (polymerizable) vesicles. 
sodium hypochlorite, followed by rinsing in distilled water. The replicas were then transferred onto 200-mesh copper grids.

\section{Enzyme Purification and Characterization}

Prior to use, the lipase preparation was purified. Dry enzyme powder (specific activity $372 \mathrm{U} / \mathrm{mg}$ protein) was suspended in $10 \mathrm{~m} M$ tris-HCL buffer ( $\mathrm{pH} \mathrm{7)}$ and was centrifuged for 30 minutes at $15,000 \mathrm{~g}$ and at $48,500 \mathrm{~g}$ at $10^{\circ} \mathrm{C}$ for 1 hour. Subsequently, the clear enzyme solution $(341 \mathrm{U} / \mathrm{mg})$ was applied to a gel permeation column (Hiload 26/60 Sephacryl S-300 HR) coupled to an automated FPLC system (Pharmacia). The columns were equilibrated and run with a $20 \mathrm{mM}$ tris- $\mathrm{HCl}$ buffer, $\mathrm{pH} \mathrm{7.1,} \mathrm{containing} 150 \mathrm{mM} \mathrm{NaCl}$. After gel filtration, $70 \%$ of the activity could be recovered from the second peak, corresponding to a specific activity of $1659 \mathrm{U} / \mathrm{mg}$ protein, and this fraction was used further in this study. Finally, the enzyme solution was desalted on a Sephadex G-25 column and freeze-fried before storage. The specific activity of the freeze-dried enzyme was $998 \mathrm{U} / \mathrm{mg}$ protein.

After purification, some characteristics of the enzyme were determined. The protein migrates to a molecular weight of $58.5 \mathrm{kD}$ on SDS-PAGE. Isoelectric focusing shows that the purified lipase has an isoelectric point of 4.1. The $\mathrm{pH}$ optimum is broad, ranging from 6 to 9; the optimum temperature for $\mathrm{CCL}$ is $45^{\circ} \mathrm{C}$ (data not shown).

\section{Enzyme Entrapment}

Lipase entrapment in vesicles is accomplished by the dehydration-rehydration method or by spontaneous incorporation. The dehydration-rehydration method, as described by Kirby and Gregoriadis, ${ }^{19}$ was slightly modified. A lipase solution $(278 \mu \mathrm{g}$ protein $/ \mathrm{mL})$ was added to freeze-dried vesicles (final protein-to-surfactant ratio: $56 \mathrm{mg}$ protein/mol surfactant). The mixture was homogenized by short sonication (microtip, level 3, pulser at 50\%), freeze-dried, and rehydrated by the addition of a proper amount of water. The slightly opaque solution was sonicated at $0^{\circ} \mathrm{C}$ (microtip, level 3, pulser at $50 \%$ ) in order to prepare unilamellar vesicles, because trapping efficiencies are reported to be higher in unilamellar vesicles than in multilamellar vesicles. $^{17,19}$ Alternatively, equal amounts of purified lipase solutions (56.4 $\mu \mathrm{g}$ protein/mL) and $5 \mathrm{mM}$ vesicle solutions (protein-to-surfactant ratio $11 \mathrm{mg} / \mathrm{mol}$ ) were mixed at room temperature, incubated for 1 hour at room temperature and subsequently for 15 hours at $4^{\circ} \mathrm{C}$. The vesicle-entrapped enzyme was isolated be centrifugation for 2 to 4 hours at $48,500 \mathrm{~g}$ at $10^{\circ} \mathrm{C}$ and was resuspended and centrifuged again in order to remove all nonentrapped enzyme. Enzymatic activity in both supernatants and pellets was measured for the determination of the trapping efficiency.

\section{Enzyme Assays}

In the standard assay method, $0.2 \mathrm{~g}$ of tributyrin was emulsified in $40 \mathrm{~mL}$ of water by 2 minutes of sonication (13-mm tip, level 8). The enzymatic hydrolysis was started by addition of a proper amount of enzyme. The assay mixtures were titrated with 2 to $10 \mathrm{mM} \mathrm{KOH}$ solutions. Base consumption due to hydrolysis of the triglycerides was monitored with an AUTOLAB/ISEC automatic titrator (Eco Chemie, Utrecht, The Netherlands). The reactions were carried out at $\mathrm{pH} 7,37^{\circ} \mathrm{C}$, and in a nitrogen atmosphere. For the determination of the enzymatic activity at variable triglyceride concentrations the assay method was slightly modified. The term "concentration" refers to the overall amount of substrate in the assay. Three substrates were tested: triacetin, tributyrin, and tricaprylin. Triacetin is soluble in water up to $6 \% \mathrm{v} / \mathrm{v}(440 \mathrm{mM})$, tributyrin is slightly soluble in water (up to $0.4 \mathrm{mM}^{37}$ ), whereas tricaprylin is insoluble in aqueous solutions. Several triglyceride solutions were prepared in acetonitrile. Assay mixtures were prepared by addition of $1 \% \mathrm{v} / \mathrm{v}$ of substrate solutions to 30 to $50 \mathrm{~mL}$ of water. In the case of tributyrin and tricaprylin, the mixtures were sonified (13-mm tip, level 8) for 2 and 5 minutes, respectively, to guarantee maximal emulsification. In the case of triacetin, the addition of base was monitored for at least 5 minutes before enzyme was added, in order to determine base consumption due to spontaneous hydrolysis. At low triacetin concentrations the blank reaction was not negligible and the final values for enzyme activity were corrected for this spontaneous hydrolysis. The enzymatic reactions were started by addition of free or incorporated CCL with a final concentration of 95 to $158 \mathrm{ng}$ protein/mL in the assay mixture.

The effect of additives on the activity of free $\mathrm{CCL}$ was tested by addition of ABHEMA $\mathrm{Br}$ (as a monomolecular dispersed solution or as nonpolymerized and polymerized vesicles) cetyltrimethylammonium bromide (CTAB), polyoxyethylene(23)lauryl ether (Brij 35), and poly(ethylenimine) (PEI) to the assay solution. The enzymatic hydrolysis was monitored for 5 minutes; then the additive was administered and the activity was again monitored for 5 minutes. Monomolecular dispersed ABHEMA $\mathrm{Br}$ was obtained by adding $0.5 \mathrm{~mL}$ of a stock solution of the surfactant in acetonitrile to the sample solution. Poly(ethylenemine) was dissolved in water and adjusted to $\mathrm{pH} 7$ before use. In these experiments, the assay mixture consisted of $50 \mathrm{~mL}$ of water, $1 \%(\mathrm{v} /)$ acetonitrile, triacetin $(15 \mathrm{~m} M)$, tributyrin $(0.32$ and $5 \mathrm{mM})$, or tricaprylin $(0.32$ and $5 \mathrm{mM})$ and $\mathrm{CCL}$ to a final concentration of $112 \mathrm{ng}$ protein $/ \mathrm{mL}$; the concentration of the additives in the assay was $5 \mu M$ on monomer basis. Mixtures containing triacetin or $0.32 \mathrm{~m} M$ tributyrin were homogeneous, whereas $5 \mathrm{mM}$ tributyrin and tricaprylin were emulsions.

All measurements were taken in triplicate or, when the standard deviation was lower than $2 \%$, in duplicate. The reaction rates for triacetin and tributyrin were linear versus 
time; however, the initial reaction rate for CCL in the case of tricaprylin was not linear in time. Initial reaction rates were extrapolated and, in addition, were determined at a point where the hydrolysis was linear (at 5 minutes reaction time). Lipase activity $(U)$ is defined as micromoles of fatty acid released per minute, conforming to the rules of the IUPAC-IUB. It was confirmed, by separate measurements, that the ester-bonds in the surfactant were not hydrolyzed by the enzyme.

\section{Tryptic Digestion}

Equal amounts of free or incorporated lipase $(113 \mu \mathrm{g}$ protein $/ \mathrm{mL}, 2.5 \mathrm{mM}$ polymerized ABHEMA Br) were mixed with a $1 \mathrm{mg} / \mathrm{mL}$ solution of trypsin in $10 \mathrm{mM}$ tris- $\mathrm{HCl}, \mathrm{pH} 8.5$, and $0.2 \mathrm{mM}$ calcium chloride, and these mixtures were incubated at $30^{\circ} \mathrm{C}$. After certain time intervals, samples were drawn from the mixture and lipase activity was determined with the standard assay method.

\section{RESULTS}

\section{Characterization of the Vesicle System}

Vesicles of the three different surfactants $N$-allylbis[2(dodecanolyloxy)ethyl]methylammonium bromide (ABDEMA Br), $N$-allylbis[2-(hexadecanoyloxy)ethyl]methylammonium bromide (ABHEMA Br) and bis[2-(10-undecenoyloxy)ethyl]dimethylammonium bromide (BUEDMA $\mathrm{Br}$ ) (see scheme) can be prepared by sonication of a surfactant suspension. Upon sonication, the mixtures became opaque. Examination of these solutions by transmission electron microscopy demonstrates that sonication produces uniformly sized, unilamellar vesicles. Figure 1 shows a typical example of a polymerized ABHEMA $\mathrm{Br}$ vesicle. The size of the vesicles is 200 to $400 \mathrm{~nm}$ and they are, therefore, regarded as large unilamellar vesicles (LUV). ${ }^{9}$

The degree of polymerization is estimated by NMR through comparison of the integration of the vinyl signals of the monomeric and the polymeric surfactants. This method revealed that the vesicles can be polymerized in water to a maximal extent of $32 \%$. In the case of prepolymerization of surfactants in THF, and subsequent vesiculation, nearly no vinyl signal can be detected.
The stability of the vesicles is controlled by the medium used. In pure water all monomeric and polymeric vesicles are stable for several months. In $10 \mathrm{~m} M$ potassium phosphate buffer ( $\mathrm{pH} 6$ or 8 ), or in $10 \mathrm{mM}$ tris- $\mathrm{HCl}$ buffer ( $\mathrm{pH} 7$ or 8.5 ), the polymeric vesicles are stable for at least 1 month. Upon prolonged standing of polymeric ABHEMA $\mathrm{Br}$ vesicles in phosphate buffer an increase in viscosity can be observed. This is most probably due to the fact that phosphate can act as a crosslinking agent between the positively charged headgroups of the surfactant polymers. In contrast, the stability of monomeric ABDEMA $\mathrm{Br}$ vesicles was restricted to several hours at $\mathrm{pH} 6$ to 7 , and even decreased to minutes when buffers of $\mathrm{pH}$ 8 or 8.5 were applied. In $100 \mathrm{mM}$ phosphate buffer, the monomeric vesicles precipitated almost instantly, whereas the polymerized analogs flocculated after several minutes (ABDEMA $\mathrm{Br}$ ) or after 12 to 15 hours (BUEDMA $\mathrm{Br}$ and ABHEMA Br).

\section{Incorporation of $\mathrm{CCL}$ in Vesicles and the Effect on Enzymatic Activity}

The incorporation of CCL in vesicles, using the dehydration-rehydration method, was investigated for two different surfactants: ABDEMA Br and BUEDMA Br. The extent of incorporation, based on activity measurements, is expressed as the trapping efficiency (Table I). Recovery is defined as the sum of the total activities of entrapped and nonentrapped lipase divided by the total activity of initially added enzyme. In the case of the use of ABDEMA Br vesicles, there is a considerable difference in activity between enzyme entrapped in polymerized or in nonpolymerized vesicles, as shown in Table I. In the case of BUEDMA Br vesicles, there is neither any difference in trapping efficiency for polymerized and nonpolymerized vesicle solutions; however, the recovery for the polymerized analog is lower. When CCL is incubated with vesicle solutions, trapping efficiencies of up to $100 \%$ can be obtained, indicating that all of the initially added enzyme is incorporated into the vesicles. However, trapping efficiencies and recoveries varied with incubation time. It appears that directly after mixing of enzyme and vesicle solutions the activity of this mixture is very low. After an incubation time of 1 hour the activity of the lipase-vesicle mixture is maximal (Fig. 2).

Table I. Trapping efficiency and recovery for CCL incorporated into ABDEMA $\mathrm{Br}$ and BUEDMA Br vescicles by means of the dehydration-rehydration method.

\begin{tabular}{ccc}
\hline CCL $_{\text {incorporated into vesicles of }}^{\mathrm{b}}:$ & Trapping efficiency $^{\mathrm{a}}(\%)$ & Recovery $^{\mathrm{a}}(\%)$ \\
\hline ABDEMA Br & & 83 \\
$\quad$ Nonpolymerized & 43 & 55 \\
$\quad$ Polymerized & 19 & 77 \\
BUEDMA Br & & \\
$\quad$ Nonpolymerized & 21 & 50 \\
\hline
\end{tabular}

\footnotetext{
a Trapping efficiency and recovery are normalized to the activity of the free enzyme $(=100 \%)$.

${ }^{b}$ Experimental details are described in the Materials and Methods section.

c The extent of polymerization is $28 \%$ and $32 \%$, respectively, for ABDEMA $\mathrm{Br}$ and BUEDMA $\mathrm{Br}$ vesicles.
} 


\section{Activity of Free and Incorporated CCL Assayed With Three Different Triglycerides}

Changes in activity by incorporating the enzyme in vesicles were investigated by comparing the activity of free versus incorporated lipase for three different triglycerides: triacetin, tributyrin, and tricaprylin. For triacetin, the lipase activity was assayed at concentrations of 0.4 to $30 \mathrm{mM}$, well below the solubility limit. The activity profile of free and incorporated Candida cylindracea lipase is plotted in Figure 3; it is clear that the activity for the incorporated lipase is higher than for the free lipase. Similar behavior can be observed in the case of tributyrin (Fig. 4). Especially at lower concentrations-near or under the solubility limit - incorporated enzyme is up to four times more active than free enzyme. Merely in tricaprylin assays the free enzyme is more active than the incorporated enzyme when looking at the initial rate of hydrolysis. However, the activities determined after 5 minutes of reaction are almost equal (Fig. 5). This is due to the fact that the reaction rates for free enzyme are not linear in time for this substrate.

\section{The Influence of Additives in the Triglyceride Assays on Activity of Free Lipase}

The influence of several additives on the system was studied by monitoring the immediate change in enzymatic activity upon their addition. The surfactant, ABHEMA Br, was added in three forms: monomolecular dispersed, as nonpolymerized vesicles, or as polymerized vesicles. The surfactants, cetyltrimethylammonium bromide (CTAB) and polyoxyethylene(23)lauryl ether (Brij 35), were added in a concentration well below their critical micelle concentration. Polyethylenimine (PEI), a postively charged polyelectrolyte at $\mathrm{pH} \mathrm{7,} \mathrm{was} \mathrm{added} \mathrm{in} \mathrm{the} \mathrm{same} \mathrm{concentration} \mathrm{as}$ the other compounds (based on ethylenimine monomer). Table II summarizes the results of the triglyceride assays at a substrate concentration of $5 \mathrm{mM}$.

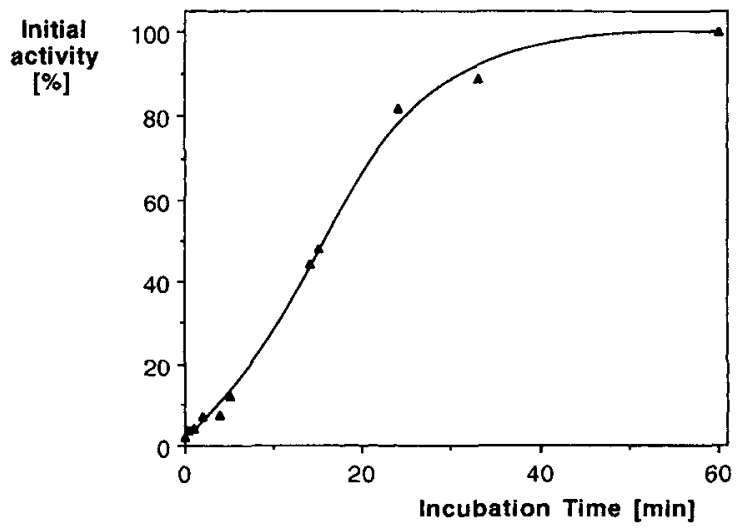

Figure 2. Time dependence of enzymatic activity during the incorporation process of $\mathrm{CCL}$ in polymerized ABHEMA Br vesicles. Equal amounts of lipase solution $(113 \mu \mathrm{g} / \mathrm{mL})$ and vesicle solution $(5 \mathrm{mM})$ were incubated at $20^{\circ} \mathrm{C}$. At various time intervals, samples were taken and the lipase activity was measured.

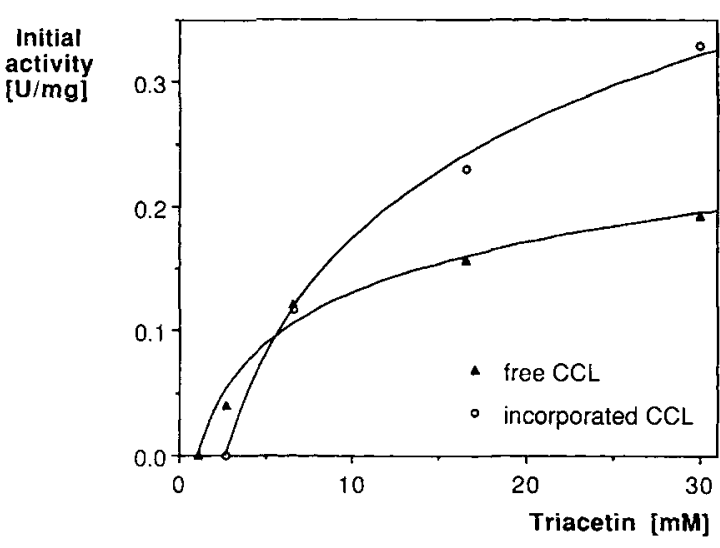

Figure 3. Activity profiles for frec CCL and CCL incorporated in polymerized ABHEMA $\mathrm{Br}$ vesicles with varying triacetin concentrations. For experimental details, see the Materials and Methods section (Enzyme Assays).

In the case of tricaprylin, lipase activity is improved more than threefold by most additives. In the tributyrin assay, the enzymatic activity is slightly reduced by polymerized vesicles and PEI, whereas CTAB and nonvesiculated ABHEMA $\mathrm{Br}$ vesicles reduce the activity nearly to zero. For nonpolymerized ABHEMA $\mathrm{Br}$, the result was not very consistent: activities dropped to $46 \%$ to $63 \%$ with a mean value of $55 \%(n=9)$. In the homogeneous assay system, addition of polymerized vesicles causes an enhancement of the hydrolytic activity, whereas addition of monomeric or nonpolymerized vesicles considerably reduce the activity. Addition of Brij 35, a nonionic surfactant, has no influence on the enzymatic activity.

For tributyrin and tricaprylin, the effect of polymerized vesicles on enzyme activity was also investigated at a substrate concentration of $0.32 \mathrm{~m} M$. The results are shown in Table III. In both cases, there is a considerable rate enhancement: for tributyrin 10 times, and for tricaprylin 9 times.

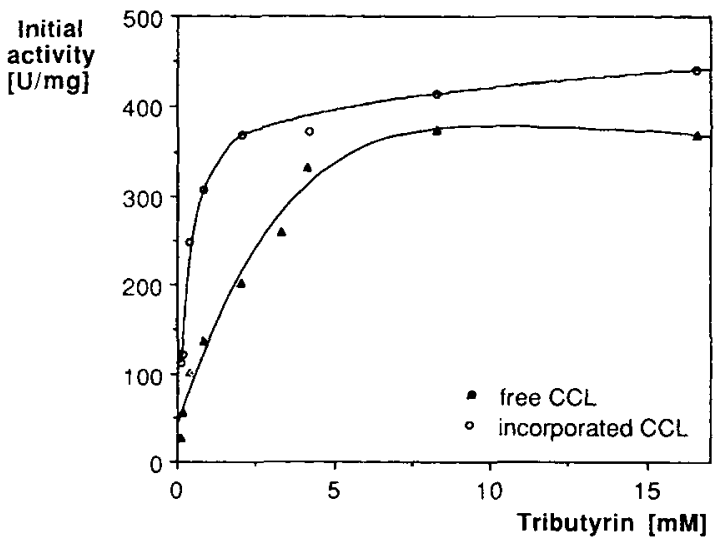

Figure 4. Activity profiles for free $\mathrm{CCL}$ and $\mathrm{CCL}$ incorporated in polymerized ABHEMA $\mathrm{Br}$ vesicles with varying tributyrin concentrations. For experimental details, see the Materials and Methods section (Enzyme Assays). 


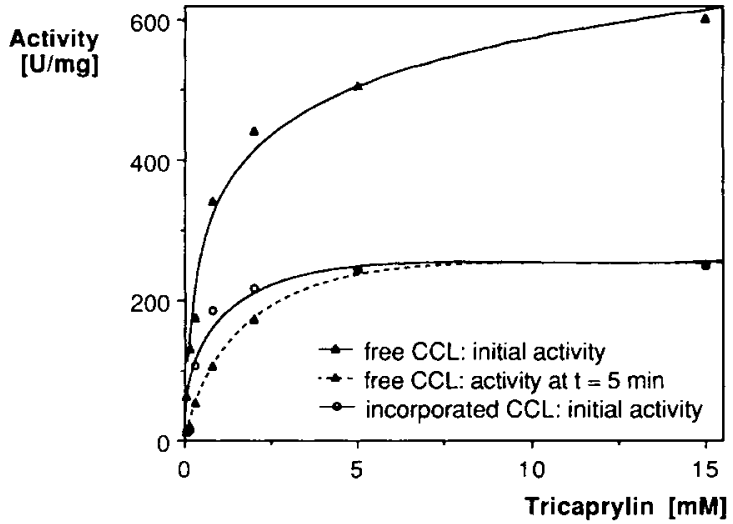

Figure 5. Activity profiles for free CCL and CCL incorporated in polymerized ABHEMA $B r$ vesicles with varying tricaprylin concentrations. Solid lines represent initial activities, dashed lines represent the activities after 5 minutes. For experimental details, see the Materials and Methods section (Enzyme Assays).

\section{Trypsin Digestion of Free and Incorporated CCL}

The stability of free and incorporated enzyme was tested by treatment of enzyme samples with the proteolytic enzyme trypsin. The effect of trypsin digestion on lipase activity is depicted in Figure 6. Activity of free lipase is reduced to $50 \%$ within 2 hours of incubation, whereas incorporated enzyme is almost not attacked by the proteolytic enzyme.

\section{DISCUSSION}

\section{Characterization of the Vesicle Systems}

Morphological investigation by the use of transmission electron microscopy confirms that the vesicle membrane structure is conserved during the dehydration process, as was claimed earlier by Kirby and Gregoriadis ${ }^{13,19}$ without giving experimental evidence. Addition of lipase to a

Table II. Influence of additives in $15 \mathrm{mM}$ triacetin and in $5 \mathrm{mM}$ tributyrin and tricaprylin assays on the activity of $C$. cylindracea lipase.

\begin{tabular}{lccc}
\hline & \multicolumn{3}{c}{ Relative initial activity } \\
\cline { 2 - 4 } Additive in assay & Triacetin & Tributyrin & Tricaprylin \\
\hline Free CCL, no additive & 100 & 100 & $100^{\mathrm{b}}$ \\
ABHEMA Br & & & \\
$\quad$ Monomolecular dispersed & 17 & 6 & 311 \\
Vesiculated, not polymerized & 3 & 55 & 309 \\
$\quad$ Vesiculated, polymerized & 140 & 85 & 345 \\
CTAB & 50 & 3 & 331 \\
Brij 35 & 100 & 100 & 100 \\
PEI & - & 70 & 312 \\
\hline
\end{tabular}

a Experimental details are described in the Materials and Methods section.

${ }^{\mathrm{b}}$ In this case, the activity after 5 minutes $(244 \mathrm{U} / \mathrm{mg})$ is taken as $100 \%$, because the rate of tricaprylin hydrolysis is not constant in time. The initial activity is $521 \mathrm{U} / \mathrm{mg}$, corresponding to $214 \%$ of the activity after 5 minutes.
Table III. Influence of additives in $0.32 \mathrm{~m} M$ triglyceride assays on the activity of $C$. cylindracea lipase.

\begin{tabular}{lcc}
\hline & \multicolumn{2}{c}{ Relative initial activity } \\
\cline { 2 - 3 } \multicolumn{1}{c}{ Additive in assay } & Tributyrin & Tricaprylin \\
\hline Free CCL, no additive & 100 & $100^{\mathrm{b}}$ \\
ABHEMA Br, vesiculated polymerized & 973 & 907 \\
\hline
\end{tabular}

a Experimental details are described in the Materials and Methods section.

${ }^{b}$ In this case, the activity after 5 minutes $(59 \mathrm{U} / \mathrm{mg}$ ) is taken as $100 \%$, because the rate of tricaprylin hydrolysis is not constant in time. The initial activity is $177 \mathrm{U} / \mathrm{mg}$, corresponding to $300 \%$ compared with the activity after 5 minutes.

vesicle solution does not alter the size of the vesicles (not shown).

Tundo et al. ${ }^{41}$ and Kippenberger et al. ${ }^{18}$ claimed that it is possible to completely polymerize the dialkylammonium bromide surfactant vesicles by ultraviolet radiation or selectively polymerized the outer surface of the membrane by thermal radical polymerization using an initiator. We did not succeed in polymerizing the vesicles by UV. radiation. Thermal radical polymerization proceeded to a maximum extent of $32 \%$, whereas Kippenberger et al. reported 56\%, corresponding to a complete polymerization of the outer vesicle surface. Although polymerization in aqueous solution takes place in a highly ordered system, we believe that the low extent of polymerization can be explained by the isolated nature of the double bond in the surfactant molecule. In order to obtain higher degrees of surfactant crosslinking, we have prepolymerized the surfactants in THF using AIBN as an initiator. In this way, it was possible to completely polymerize the surfactants, although vesiculation of the oligomeric surfactants was more difficult than in the case of the monomeric surfactants, as is reflected by the increased sonication times. Due to the polymerization, the vesicles were appreciably more stable

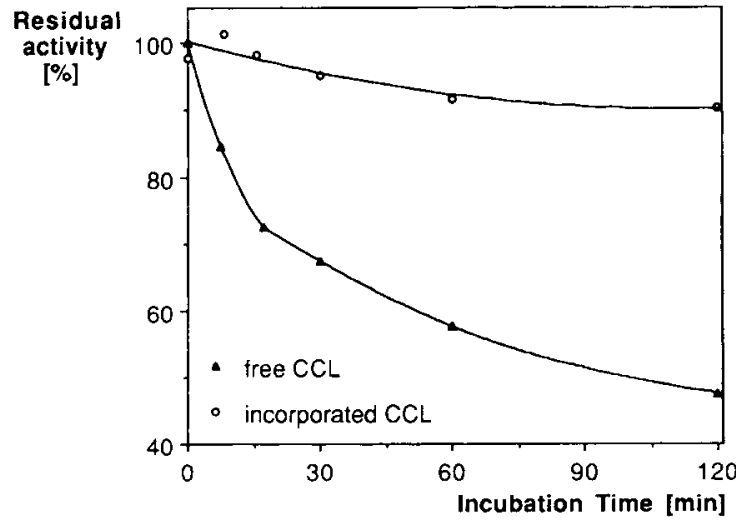

Figure 6. The stability of free CCL and incorporated CCL (polymerized ABHEMA Br vesicles) in the presence of trypsin. For experimental details, see the Materials and Methods section (Tryptic Digestion). 
than their nonpolymerized analogs. This clearly shows the advantage of the use of polymerizable surfactants.

\section{Purification and Characterization of C. cylindracea Lipase}

The commercial lipase preparation has a protein content of $15 \%$, of which one third is the active lipase, according to the supplier. Candida cylindracea lipase was purified in three steps, resulting in a sample with a protein content of $56.4 \%$ and a specific activity of $998 \mathrm{U} / \mathrm{mg}$ protein. The elution profile of the Sephacryl S-300 column indicated that lipase OF (Meito Sangyo) is a mixture of proteins, which all have some lipase activity. The most active fraction is used further in this work; this enzyme fraction is referred to as CCL. This protein has nearly the same elution volume as the marker protein $\mathrm{BSA}(66 \mathrm{kD})$ on the gel permeation column; the molecular weight of the protein is $58.5 \mathrm{kD}$ on SDS-PAGE, and is therefore considered to be monomeric. It is clear that it is possible to purify CCL to a considerable extent by simple techniques. Comparing our data and the data from literature, ${ }^{36,39,42}$ it seems very likely that different Candida preparations or batches contain different enzymes. Therefore, it is advisable, depending on the application, to characterize the sample that is used.

\section{Incorporation of $\mathrm{CCL}$ in Vesicles}

Several techniques for the entrapment of biologically active substances in vesicles have been proposed. ${ }^{11,23}$ Initially, we have used the dehydration-rehydration method for the incorporation of CCL in vesicles. This method is attractive because mild conditions can be used: no organic solvents and no or only very short sonication are required, which may inactivate the enzyme. Using this method, trapping efficiencies for proteins vary from $1 \%$ to $40 \%,{ }^{14,19}$ and even with the same proteins large variations are possible when, for instance, the protein-to-surfactant ratio is changed. In our studies, the trapping efficiency varied from $19 \%$ to $43 \%$ (Table I), although we have not tried to optimize the entrapment.

Because the dehydration-rehydration method is rather laborious, we have investigated the possibility of direct incorporation of the enzyme into vesicles in solution. Therefore, lipase was added to a polymerized vesicle solution, incubated for 1 hour, and the activity of the mixture assayed at various (incubation) time intervals, was measured. The results are plotted in Figure 2 and show that lipase activity directly after mixing is rather low, but that it is restored to $100 \%$ within 1 hour. Fluorescence studies reveal that there is an initial fast interaction between lipase and vesicle, most probably caused by electrostatic attraction of the oppositely charged enzyme and vesicle surface. ${ }^{26,45}$ Subsequently, the hydrophobic part of the vesicle membrane will induce further incorporation of the enzyme into the vesicle membrane. ${ }^{17,46}$ Insertion of the protein into the bilayer will be accompanied by rearrangement of surfactant molecules around the enzyme and by changes in its state of hydration, the distribution of charged groups, and other rearrangements in the protein structure. ${ }^{31,32}$ These processes may-especially in the case of polymerized vesicles-be responsible for the fact that enzymatic activity is initially lowered upon mixing of the enzyme with vesicles. ${ }^{7,16}$

\section{Activity of Free Versus Incorporated CCL for Triglycerides}

The effect of vesiculation upon enzyme activity is studied with a series of triglycerides with increasing hydrophobicity, viz. triacetin, tributyrin, and tricaprylin. Triacetin is used in a concentration range well below its solubility limit, and both enzyme preparations have low hydrolysis rates over the whole concentration range when compared to emulsified substrates (Fig. 3). At very low concentrations, no base consumption could be detected within the assay time. The activity of incorporated enzyme is higher than for free enzyme. This may be caused by the catalytic mechanism of lipases. Recently, the structure of three lipases has been elucidated: human pancreatic lipase, ${ }^{44}$ Rhizomucor miehei lipase, ${ }^{4}$ and Geotrichum candidum lipase. ${ }^{35}$ The active site in these enzymes is buried and covered by a hydrophobic flap. The lipases can be activated by moving this flap away from the active center. ${ }^{5}$ This is accomplished by contacts between a hydrophobic surface and the protein. ${ }^{15}$ In a comparative analysis of lipases, Kordel et al. ${ }^{21}$ found that many lipases have structural similarities. Solubilized substrates, like triacetin, lack an interface that can remove the flap, i.e., activate the enzyme, and-in general-therefore lead to much lower enzyme activities than emulsified substrates. Recent crystallographic studies confirm that binding of lipase is accompanied by structural changes essential for the activation of the enzyme. ${ }^{6}$ In the case of entrapment in vesicles, the lipase is activated by the membrane bilayer, which induces the conformational changes in the enzyme. This explains why the incorporated enzyme has a higher activity for triacetin than the free enzyme. At low tributyrin concentrations - the solubility limit of tributyrin is $0.44 \mathrm{~m} M$ - the activation of the enzyme by incorporation in vesicles is even more pronounced (Fig. 4). The incorporated enzyme is up to 4 times more active than the free CCL.

In tricaprylin emulsions, the free enzyme is more active than the entrapped enzyme when comparing initial activities (Fig. 5). However, the reaction rate of the free enzyme gradually decreases during the initial stage of the reaction until a constant rate of $47 \%$ of the initial value is reached within 4 minutes. On the other hand, in the case of incorporated lipase, the reaction rate hardly changes with time. The decreasing rate in the reaction of the free enzyme is most probably caused by the accumulation of caproate at the substrate-water interface, thereby decreasing the accessibility of the enzyme to the substrate. ${ }^{1}$ A second contribution to the decrease in activity of the free enzyme might be the interaction of the carboxylate anion with the enzyme. It has been found that fatty acids can act as 
competitive inhibitors. ${ }^{40}$ In the case of incorporated lipase, the vesicle bilayer can accomodate in the caproate, thereby preventing the pollution of the substrate interface. ${ }^{2}$

\section{Effect of Additives on Lipase Activity in Triglyceride Assays}

In the triacetin assay, only addition of polymerized vesicles yields an increased activity (Table II). The conclusion that introduction of a hydrophobic interface stimulates the lipase activity is underlined further by the tenfold enhancement of the activity in the assay with solubilized tributyrin (see Table III). The decrease in activity by addition of nonpolymerized vesicles to the enzyme-substrate system may be due to the presence of the ester bond in the surfactant. Although these ester groups are not hydrolyzed by the enzyme, they can act as inhibitors. As vesiculated ABHEMA Br provides an interface for the enzyme, the ester groups in this system can be more effective in the inhibition process than those in monomoleculardispersed ABHEMA Br. In the tributyrin assay, where the free enzyme is already adsorbed to the substrate droplets before the addition of vesicle solution, this effect seems to play a minor role. CTAB is reported earlier to be an effective inhibitor for lipases. ${ }^{34}$ In the case of tricaprylin as substrate, all positively charged additives increase the activity. Clearly, the inhibitory effect of the negatively charged caproate is prevented by association with these additives. In our case, the addition of the nonionic surfactant Brij 35 has no effect, although in literature it is reported that polyoxyethylene ethers can enhance the activity. ${ }^{30}$

\section{Trypsin Digestion of Free and Incorporated Lipase}

Free lipase is inactivated by trypsin as the result of hydrolysis of the peptide bonds. For the incorporated CCL, the major backbone of the enzyme is buried in the vesicle bilayer. The lipase is therefore not accessible for trypsin, resulting in a considerably higher residual activity than in the case of free lipase (Fig. 6). This clearly demonstrates the protective influence of the vesicle bilayer. Similar results were obtained by Miranda et al. ${ }^{24}$ in their studies on mushroom tyrosinase, incorporated in lecithin-cholesterol vesicles.

\section{CONCLUSIONS}

This study shows that Candida cylindracea lipase can be effectively entrapped in vesicles by simple incubation. In most cases, compared with free enzymes, vesicleincorporated lipases have a higher activity in the hydrolysis of triglycerides due to interfacial activation. Incorporation of enzymes in vesicles increases their stability toward surfactant additives and proteolytic attack, which can make this system useful for drug targeting or in detergent formulations, where surfactant systems are already used for enzyme stabilization. Vesicle-enzyme mixtures are optically clear, so they can be used in studies with spectroscopic techniques. ${ }^{27}$ Understanding of enzyme-vesicle interactions may lead to the development of multienzyme systems in vesicles, which can be used as microbioreactors.

A. C. van Aelst from the Department of Plant Cytology and Morphology (Wageningen Agricultural University) is acknowledged for his help in the electron microscopic studies. R. Wolbert from the Department of Biochemistry (Wageningen Agricultural University) is acknowledged for his assistance in the purification and analysis of CCL.

\section{References}

1. Benzonana, C., Desnuelle, P. 1968. Action of some effectors on the hydrolysis of long-chain triglycerides by pancreatic lipase. Biochim. Biophys. Acta 164: 47-58.

2. Borgström, B. 1977. The action of bile salts and other detergents on pancreatic lipase and the interaction with colipase. Biochim. Biophys. Acta 488: $381-391$.

3. Borgström, B., Brockman, H. L. (eds.) 1984. Lipases. Elsevier, Amsterdam; p. 527.

4. Brady, L., Brzozowski, A. M., Derewenda, Z. S., Dodson, E., Dodson, G., Tolley, S., Turkenburg, J.P., Cristiansen, L., Huge-Jensen, B., Norskov, L., Thim, L., Menge, U. 1990. A serine protease triad forms the catalytic centre of a triacylglycerol lipase. Nature 343, 767-770.

5. Brzozowski, A. M., Derewenda, U., Derewenda, Z. S., Dodson, G. G., Lawson, D. M., Turkenburg, J.P., Björkling, F., Huge-Jensen, B., Patkar, S. A., Thim, L. 1991. A model for interfacial activation in lipases from the structure of a fungal lipase-inhibitor complex. Nature 351: $491-494$.

6. Derewenda, U., Brzozowski, A. M., Lawson, D. M., Derewenda, Z.S. 1992. Catalysis at the interface: the anatomy of a conformational change in a triglyceride lipase. Biochemistry 31: 1532-1541.

7. Ekíz, H. I., Çaglar, M. A., Uçar, T. 1988. A rapid equilibrium approach to the interfacial kinetics of lipid hydrolysis by a Candida lipase. Chem. Eng. J. 38: B7-B11.

8. Eytan, G. D. 1982. Use of liposomes for reconstitution of biological functions. Biochim. Biophys. Acta 694: 185-202.

9. Fendler, J. H. 1982. Membrane mimetic chemistry. Wiley, New York.

10. Fendler, J. H. 1985. Membrane mimetic systems that contain catalysts, semiconductors and magnets. Chemtech 15: 686-691.

11. Gregoriadis, G. (eds.) 1984. Liposome technology (incorporation of drugs, proteins and genetic material), vol. 2. CRC Press, Boca Raton, FL.

12. Gregoriadis, G. (eds.) 1984. Liposome technology (preparation of liposomes), vol. 1. CRC Press, Boca Raton, FL.

13. Gregoriadis, G. (1985). Liposomes for drugs and vaccines. Trends Biotechnol. 3: 235-241.

14. Gregoriadis, G. 1987. Encapsulation of enzymes and other agents in liposomes. Spec. Publ. R. Soc. Chem. 63: 94-105.

15. Gubernator, K., Müller, K., Winkler, F. K. 1991. The structure of human pancreatic lipase suggests a locally inverted, trypsin-like mechanism, pp. 9-16. In: L. Alberghina, R. D. Schmid, and R. Verger (eds.), Lipases: structure, mechanism and genetic engineering. GBF monographs, vol. 16. VCH Verlagsgesellschaft, Weinheim.

16. Iwai, M., Shimada, Y., Tsujisaka, Y. 1980. Modification of Rhizopus delemar lipase by its binding with phospholipids. J. Biochem. 88: 533-538.

17. Kimelberg, H. K. 1976. Protein-liposome interactions and their relevance to the structure and function of cell membranes. Mol. Cell. Biochem. 10: 171-190.

18. Kippenberger, D., Rosenquist, K., Odberg, L., Tundo, P., Fendler, J. H. 1983. Polymeric sufactant vesicles. Synthesis and characterization by NMR spectroscopy and dynamic laser light scattering. J. Am. Chem. Soc. 105: 1129-1135. 
19. Kirby, C., Gregoriadis, G. 1984. Dehydration-rehydration vesicles: a simple method for high yield drug entrapment in liposomes. Biotechnology 2: 979-984.

20. Klibanov, A.M. 1989. Enzymatic catalysis in anhydrous organic solvents. Trends Biochem. Sci. 14: 141-144.

21. Kordel, M., Menge, U., Morelle, G., Erdmann, H., Schmid, R.D 1991. Comparative analysis of lipases in view of protein design, pp. 421-424. In: L. Alberghina, R. D. Schmid, and R. Verger (eds.). Lipases: structure, mechanism and genetic engineering, GBF monographs, vol. 16. VCH Verlagsgesellschaft, Weinheim.

22. Martinek, K., Klyachko, N. L., Kabanov, A. V., Khmelnitsky, Y.L., Levashov, A. V. 1989. Micellar enzymology: its relation to membranology. Biochim. Biophys. Acta 981: 161-172.

23. Mayer, L. D., Bally, M. B., Hope, M.J., Cullis, P. R. 1986. Techniques for encapsulating bioactive agents into liposomes. Chem. Phys. Lipids 40: $333-345$.

24. Miranda, M., Amicarelli, F., Ragnelli, A. M., Poma, A., Arcadi, A. 1989. Effect of cholesterol on the DOPA oxidase of liposomeintegrated mushroom tyrosinase. Colloids Surf. 35: 353-358.

25. Mosmuller, E.W. J., Engbersen, J.F. J. 1990. Activity of enzymes entrapped in synthetic surfactant vesicles. In: H. Breteler, R.F. Beudeker, and K.C.A.M. Luyben, (eds.). Proceedings of the 3rd Netherlands Biotechnology Congress 1990, vol. 1. Netherlands Biotechnological Society, Zeist.

26. Mosmuller, E.W.J., Pap, E.H.W., Visser, A.J.W.G., Engbersen, J.F.J. Fluorescence studies on the interaction between lipase and polymerisable surfactant vesicles. (to appear).

27. Mosmuller, E. W. J., Van Heemst, J. D. H., Van Delden, C. J., Franssen, M. C. R., Engbersen, J.F. J. 1992. A new spectrophotometric method for the detection of lipase activity using 2,4-dinitrophenyl butyrate as a substrate. Biocatalysis 5: 279-287.

28. Mukherjee, K.D. 1990. Lipase-catalyzed reactions for modification of fats and other lipids. Biocatalysis 3: 277-293.

29. Nagao, A., Kito, M. 1990. Lipase-catalyzed synthesis of fatty acid esters useful in the food industry. Biocatalysis 3: 295-305.

30. Nakagawa, A., Tsujita, T., Okuda, H. 1984. Effect of Brij 58 on the hydrolysis of methyl butyrate by lipase from Pseudomonas fuorescens. J. Biochem. 96: 815-820.

31. Norde, W., Lyklema, J. 1991. Why proteins prefer interfaces. J. Biomater. Sci. Polym. Ed. 2: 183-202

32. Rialdi, G., Battistel, E., Barisas, B.G. 1991. Thermodynamics of enzymes in unusual environments. Thermochim. Acta 193: 349-361.

33. Ringdorf, H., Schlarb, B., Venzmer, J. 1988. Molecular architecture and function of polymeric oriented systems: models for the study of organization, surface recognition, and dynamics of biomembranes. Angew. Chem. Int. Ed. Eng. 27: 113-158.

34. Schomäcker, R., Robinson, B. H., Fletcher, P.D. I. 1988. Interaction of enzymes with surfactants in aqueous solution and in water-in-oil microemulsions. J. Chem. Soc. Faraday Trans. 1 84: $4203-4212$.

35. Schrag, J.D., Li, Y., Wu, S., Cygler, M. 1991. Ser-His-Glu triad forms the catalytic site of the lipase from Geotrichum candidum. Nature 351: 761-764.

36. Shaw, J. F., Chang, C. H., Wang, Y. J. 1989. Characterization of three distinct forms of lipolytic enzyme in a commercial Candida lipase preparation. Biotechnol. Lett. 11: 779-784.

37. Sobotka, H., Glick, D. 1934. Lipolytic enzymes. I. The mechanism of lipolytic enzyme. J. Biol. Chem. 105: 199-219.

38. Tatara, T., Fujii, T., Kawase, T., Minagawa, M. 1985. Studies on applications of lipolytic enzymes in detergency II. Evaluation of adaptability of various kinds of lipases in practical laundry conditions. J. Am. Oil Chem. Soc. 62: 1053-1058.

39. Tomizuka, N., Ota, Y., Yamada, K. 1966. Studics on lipase from Candida cylindracea. Part I. Purification and properties. Agric. Biol. Chem. 30: 576-584.

40. Tsai, S.-W., Chiang, C.-L. 1991. Kinetics, mechanism, and time course analysis of lipase-catalyzed hydrolysis of high concentration olive oil in AOT-isooctane reversed micelles. Biotechnol. Bioeng. 38: $206-211$.

41. Tundo, P., Kippenberger, D. J., Klahn, P. L., Pricto, N.E., Jao, T.-C., Fendler, J.H. 1982. Functionally polymerized surfactant vesicles. Synthesis and characterization. J. Am. Chem. Soc. 104: $456-461$.

42. Vecraragavan, K., Gibbs, B.F. 1989. Detection and partial purification of two lipases from Candida rugosa. Biotechnol. Lett. 11: $345-348$.

43. Verger, R. 1980. Enzyme kinetics of lipolysis. Meth. Enzymol. 64: $340-392$.

44. Winkler, F. K., D'Arcy, A., Hunziker, W. 1990. Structure of human pancreatic lipase. Nature 343: $771-774$.

45. Wolbert, R. B. G., Hilhorst, R., Voskuilen, G., Nachtegaal, H., Dekker, M., Van't Riet, K., Bijsterbosch, B. H. 1989. Protein transfer from an aqueous phase into reversed micelles. The effect of protein size and charge distribution. Eur. J. Biochem. 184: 627-633.

46. Zakim, D., Scotto, A.W. 1989. Spontaneous insertion of integral membrane proteins into preformed unilamellar vesicles. Meth. Enzymol. 171: $253-264$. 